\title{
Grading standards and their effect on estimates of variance components and genetic trends in the silver fox (Vulpes vulpes L.)
}

\author{
H. Wierzbicki and A. Filistowicz \\ Wrocław Agricultural University, \\ Department of Genetics and Animal Breeding \\ Kożuchowska 7, 51-631 Wrocław, Poland
}

(Received 22 April 2002; revised version 24 October 2002; accepted 20 December 2002)

\begin{abstract}
A data set of 3637 records collected on two Polish fox farms in 1985-1999 was used to estimate variance components and genetic trends in a population of the silver fox. In order to evaluate the effect of the new grading standard (introduced in 1997) on variance components and genetic progress, the trait scores from the original data set were transformed into scores of the new grading standard. Variance components were estimated by the restricted maximum likelihood (REML) method using the average information (AI) algorithm. A linear model that included herd, year of birth and birth season as fixed effects and additive genetic was used as a random effect. The annual genetic trend for the studied traits was estimated as regression of breeding value on time. It was found that the new grading standard had a small effect on variance components and derived heritabilities of the traits. The estimates of heritability derived from the original data ranged from $0.182( \pm 0.031)$ to 0.553 ( \pm 0.040 ), and although somewhat higher, were comparable to those derived from the transformed data, which ranged from $0.190( \pm 0.032)$ to $0.355( \pm 0.039)$. The genetic trends estimated for the traits graded according to the old grading standard ranged from -0.019 to 0.231 , and in general were higher than those estimated for the traits evaluated according to the new grading standard (ranging from -0.007 to 0.167 ).
\end{abstract}

KEY WORDS: genetic trend, grading standard, heritability, silver fox, variance components

* Supported by the State Committee for Scientific Research, Grant No. 3 P06D 01823 


\section{INTRODUCTION}

Subjective visual assessment of animals by classifiers is undertaken for several different traits in farm animals, e.g., linear type classification, body condition score, or carcass conformation. Training sessions are required to ensure that classifiers rank animals consistently, i.e. to achieve repeatability between classifiers and within a classifier (Veerkamp et al., 2001). The consistency of linear morphological assessment and its interpretation is strongly influenced by the so-called classifier effect (de la Fuente et al., 1996). The assessment of conformation traits can also be biased by the general appearance, size, age and sex of the animal, which affect the classifier's accuracy. Moreover, the definition of assessed morphological traits might not be sufficiently accurate, especially in complex traits such as general appearance (Goyache et al., 2001).

Another aspect of subjectively evaluated traits is the fact that an animal cannot receive a higher score than the highest category allowed for the trait. The effect of this limit may shrink the genetic variability that is present in the population (Schaeffer et al., 2001).

The selection of foxes kept on farms, both arctic (Alopex lagopus) and silver (Vulpes vulpes), has always been oriented towards improvement of conformation and coat traits as well as reproductive performance. Fox conformation and coat traits are measured/ evaluated qualitatively rather than continuously, and grading standards have been introduced for this type of trait. Classifiers grade young animals in November and give scores for either overall coat quality or separately for each trait. Arbitrarily assigned scores introduce a large amount of measurement error that appears as environmental variance if components of variance are estimated (Falconer and Mackay, 1996).

In Poland, foxes are graded using a new grading standard that has replaced the old system of evaluation. According to the old grading standard seven traits of the silver fox were scored and the sum of scores resulted in the total score. Although the definition of the scored traits was accurate, different classifiers interpreted them differently. The high subjectivity of the system (seven traits - many details) negatively influenced genetic progress, and was criticized by the people involved in fox breeding (Jeżewska and Maciejowski, 1983; Jeżewska et al., 1994). The new grading standard introduced in 1997 takes into account only four traits, and is considered to be more objective. Since the introduction of the new standard, only four, but more complex, coat and body traits are scored in Polish silver fox breeding.

This paper reports on the effect of the new grading standard on variance components and heritabilities of coat and body traits as well as genetic progress in silver foxes.

\section{MATERIAL AND METHODS}

Data collected on two Polish fox farms in 1985-1999 were used to estimate variance components and genetic trends in a population of the silver fox. The original 
data set (SET1 - 3537 records, 849 base animals) contained information on 8 performance traits (body size and conformation - BSC, colour type - CT, colour purity - CP, purity of silvering - PS, coat density - CD, hair length - HL, general appearance - GA, and the total score - TS) graded according to the old grading standard, used until 1997. To evaluate the effect of the new grading standard (introduced in 1997) on the estimates of variance components and genetic trends, the trait scores from SET1 were transformed to the scores of the new grading standard. The transformation was done by an experienced classifier who had graded the foxes. The new data set (SET2) consisted of 3568 records ( 872 base animals; 31 new records of foxes graded in 1998 - 1999 only according to the new grading standard were added) of 5 traits (body size and conformation - BSC, colour type - CT, colour and silvering purity - CSP, quality of hair coat - QHC, and total score - TS) and was obtained in the following way: new $\mathrm{BSC}=$ old $\mathrm{BSC}+$ old GA, new CT $=$ old $\mathrm{CT}$, new $\mathrm{CSP}=$ old CP + old PS, and new $\mathrm{QHC}=$ old CD + old HL. Summed were the scores that according to the new grading standard had to be graded jointly. After grading, the scores were summed giving the total score which was the main selection criterion. The selection pressure put on each trait differed, hence each trait had its own scale of scores. The animals were evaluated by the classifier when the fur coat was fully developed (November each year). Descriptions of the scale of scores and statistical information on the data sets are given in Tables 1 and 2. Pedigrees were traced back to two generations.

TABLE 1

Statistical description of the studied traits (SET1 - old grading standard) $(n=3537)$

\begin{tabular}{lcccc}
\hline Trait & Scale of scores & Mean & SD & $\begin{array}{c}\text { Coefficient of } \\
\text { variation, \% }\end{array}$ \\
\hline Body size and conformation & $0-6$ & 4.62 & 1.25 & 27 \\
Colour type & $0-3$ & 2.54 & 0.72 & 28 \\
Colour purity & $0-3$ & 2.49 & 0.56 & 22 \\
Purity of silvering & $0-3$ & 2.79 & 0.43 & 15 \\
Coat density & $0-6$ & 5.32 & 0.53 & 10 \\
Hair length & $0-6$ & 5.39 & 0.68 & 13 \\
General appearance & $0-3$ & 2.89 & 0.33 & 11 \\
Total score & $0-30$ & 26.05 & 2.05 & 7.8 \\
\hline
\end{tabular}

TABLE 2

Statistical description of the studied traits (SET2 - new grading standard) $(\mathrm{n}=3568)$

\begin{tabular}{lcrcc}
\hline Trait & Scale of scores & Mean & SD & $\begin{array}{c}\text { Coefficient of } \\
\text { variation, \% }\end{array}$ \\
\hline Body size and conformation & $0-6$ & 5.04 & 1.34 & 26 \\
Colour type & $0-3$ & 2.55 & 0.72 & 28 \\
Colour and silvering purity & $0-5$ & 4.33 & 0.70 & 16 \\
Quality of hair coat & $0-6$ & 5.00 & 0.52 & 10 \\
Total score & $0-20$ & 16.92 & 1.89 & 11 \\
\hline
\end{tabular}


The estimation of variance components was performed using the restricted maximum likelihood (REML) method via the average information (AI) under an animal model. No data transformation removing the so-called scale effect was employed since experimental observations should describe the genetic properties of the population, while a scale transformation obscures rather then illuminates the description (Falconer and Mackay, 1996). Moreover, according to Fernandez and Steel (1998) the existing toolbox for handling skewed and heavy-tailed data seems rather limited, and the implementation of these approaches is complicated and they lack flexibility and ease of interpretation. A variance of the likelihood function values of less than $10^{-8}$ was chosen as a convergence criterion. The computations were performed using the DMU 6.4 package (Madsen and Jensen, 2000). The following multitrait mixed model was applied:

$$
Y_{i j k l}=\mu+h_{i}+y_{j}+s_{k}+a_{i j k l}+e_{i j k l}
$$

where: $Y_{i j k l}$ is the ijkl-th observation, $h_{i}$ is the fixed effect of $i$-th herd $(i=1,2), y_{j}$ is the fixed effect of $\mathrm{j}$-th birth year $(j=1,2, \ldots,-15), s_{k}$ is the fixed effect of $\mathrm{k}$-th birth season $(k=1,2,3), a_{i j k l}$ is the additive genetic effect of a ijkl-th animal, and $e_{i j k l}$ is the residual effect connected with ijkl-th observation. The effects of animal and residual were assumed random with $\mathrm{E}(\mathbf{a})=\mathbf{0}, \mathrm{E}(\mathbf{e})=\mathbf{0}$, $\operatorname{var}(\mathbf{a})=\mathbf{A} \otimes \mathbf{G}_{\mathbf{0}}$ and $\operatorname{var}(\mathbf{e})=\mathbf{I} \otimes \mathbf{R}_{\mathbf{0}}$, where $\mathbf{A}$ is additive relationship matrix, $\mathbf{G}_{\mathbf{0}}$ is the additive genetic (co)variance matrix, $\mathbf{I}$ is identity matrix and $\mathbf{R}_{\mathbf{0}}$ is the (co)variance matrix for residuals, $\otimes$ is the Kronecker product. The standard errors for the estimates were derived from the AI information matrix.

After estimation of the variance components, estimated breeding values (EBVs) for the studied traits were computed using BLUP (Best Linear Unbiased Prediction) with the above animal model. The genetic trends were estimated as a regression of average annual EBVs on time.

\section{RESULTS AND DISCUSSION}

Estimates of variance components and heritabilities are presented in Table 3 (SET1) and Table 4 (SET2). The additive genetic variance components estimated for the 8 traits scored according to the old grading standard ranged from 0.027 to 0.936, and with the exception of BSC were comparable to those estimated using the new grading standard data (ranging from 0.049 to 0.907 ). For traits that can be compared directly, the estimates of additive genetic variance estimated using SET1 and SET2 were: 0.248 and 0.367 for BS, 0.158 and 0.149 for CT, and 0.936 and 0.907 for TS, respectively. The other traits (CP, PS, CD, HL, and GA - SET1, and CSP and QHC - SET2) could not be compared directly, but in general they were 
Estimates of variance components and heritabilities (SET1)

\begin{tabular}{lllll}
\hline Trait & $\hat{\boldsymbol{\sigma}}_{a}^{2}$ & $\hat{\boldsymbol{\sigma}}_{e}^{2}$ & $\hat{h}^{2}$ & s.e. \\
\hline Body size and conformation & 0.248 & 0.634 & 0.281 & $( \pm 0.036)$ \\
Colour type & 0.158 & 0.267 & 0.371 & $( \pm 0.040)$ \\
Colour purity & 0.077 & 0.151 & 0.339 & $( \pm 0.037)$ \\
Purity of silvering & 0.027 & 0.116 & 0.191 & $( \pm 0.032)$ \\
Coat density & 0.050 & 0.225 & 0.182 & $( \pm 0.031)$ \\
Hair length & 0.080 & 0.215 & 0.272 & $( \pm 0.034)$ \\
General appearance & 0.058 & 0.047 & 0.553 & $( \pm 0.037)$ \\
Total score & 0.936 & 1.751 & 0.348 & $( \pm 0.038)$ \\
\hline
\end{tabular}

$\hat{\sigma}_{a \text { - estimate of additive genetic variance, }}^{2} \hat{\sigma}_{e}^{2}$ - estimate of error variance, $\hat{h}^{2}$ - estimate of heritability, s.e. - approximated standard error of heritability estimates in parentheses, SET1 - original data

TABLE 4

Estimates of variance components and heritabilities (SET2)

\begin{tabular}{lllll}
\hline Trait & $\hat{\boldsymbol{\sigma}}_{a}^{2}$ & $\hat{\boldsymbol{\sigma}}_{e}^{2}$ & $\hat{\boldsymbol{h}}^{2}$ & s.e. \\
\hline Body size and conformation & 0.367 & 0.997 & 0.269 & $( \pm 0.036)$ \\
Colour type & 0.149 & 0.270 & 0.355 & $( \pm 0.039)$ \\
Colour and silvering purity & 0.103 & 0.291 & 0.263 & $( \pm 0.034)$ \\
Quality of hair coat & 0.049 & 0.198 & 0.190 & $( \pm 0.032)$ \\
Total score & 0.907 & 1.889 & 0.324 & $( \pm 0.032)$ \\
\hline
\end{tabular}

$\hat{\sigma}_{a}^{2}$ - estimate of additive genetic variance, $\hat{\sigma}_{e}^{2}$ - estimate of error variance, $\hat{h}^{2}$ - estimate of heritability, s.e. - approximated standard error of heritability estimates in parentheses, SET2 - transformed data

characterized by lower estimates of additive genetic variance (ranging from 0.027 to 0.103 ). In respect to error variance similar conclusions to those presented above can be drawn. The new grading standard did not markedly change the error variance estimates for CP and TS, whereas a significant difference was found as far as BSC was concerned (0.634 vs 0.997 for SET1 and SET2, respectively).

The estimates of heritabilities (Tables 3 and 4), although somewhat lower for the 5 traits scored according to the new grading standard, can be considered comparable. Heritabilities derived from the variance components of SET1 ranged from 0.191 to $0.553( \pm 0.031-0.040)$, whereas those derived from the variance estimates of SET2 ranged from 0.190 to 0.355 ( \pm 0.032 - 0.039). The estimates of heritabilities for the traits included in both, the old and new grading standards, did not differ markedly (BSC -0.281 vs 0.269 , CT -0.371 vs 0.355 , TS -0.348 vs 0.324 , respectively). 
In earlier research Wierzbicki (2000) studied the effect of data transformation on estimates of additive genetic and error variances in a population of an arctic fox (Alopex lagopus). Similar heritabilities were found to those presented here, for BS $(0.288 \pm 0.047)$, CT $(0.342 \pm 0.049)$, and TS $(0.374 \pm 0.037)$. However, the heritabilities were estimated after application of probit transformation of the data set. The estimates of heritability derived using non-transformed data were markedly higher and ranged from 0.461 for BS to 0.494 for TS. In contrast, Filistowicz et al. $(1999,2000)$ carried out studies in populations of silver and golden fox, respectively, and reported significantly lower heritabilities for CT (ranging from 0.08 to $0.168)$ and for BS (0.081). However, the estimates of heritability had high standard errors (from 0.07 to 0.14 ).

Heritabilities of conformation traits (scored by a classifier) reported for other domesticated species are usually low or moderate (Manfredi et al., 2001; Schaeffer et al., 2001; Serenius et al., 2001). Although the same traits of body conformation are evaluated in different species (for example, body size and general appearance) the genetic parameters estimated for these traits cannot easily be compared since the evaluation standards differ between species, and change in the course of time. While continuous revision of standards is desirable from a breed improvement standpoint, the consequences are that it is impossible to genetically compare individuals classified many years apart (Schaeffer et al., 2001).

The effect of the score limit and its negative influence on genetic variability in the population indicated by Schaeffer et al. (2001), seems to be supported by the results of the present study (Tables 1 and 2). Averages of the traits are very close to optimal scores (upper limits), and their standard deviations as well as variation coefficients (except BSC and CT) are small indicating that a narrow scale of scores is used when evaluating the traits.

The old grading standard has been replaced by the new one mainly because of its high subjectivity (many details of coat and conformation traits had to be evaluated) which lead in consequence to unsatisfactory genetic progress. Low precision of that type of evaluation was indicated by Jeżewska and Maciejowski (1983) who found low repeatability of scores ranging from 0.25 to 0.66 in populations of silver fox, arctic fox and mink. According to Jeżewska et al.(1994) only $21-54 \%$ of the total variation of scores was determined by animals, whereas up to $60 \%$ of the total variation was defined as an error variance.

The effects of grading standards on genetic progress are shown in Tables 5 and 6 . The estimated genetic trends were a little higher when SET1 was analysed (ranged from -0.019 to 0.231) as compared with those estimated using SET2 (ranged from -0.007 to 0.167 ). For the three traits scored using both, the old and new grading standards the following estimates of genetic trends were found: BSC: 0.146 vs 0.120 , CT: 0.034 vs 0.033 , and TS: 0.231 vs 0.167 , respectively. The wider range of the trend values estimated using SET1, among which three were negative 
Genetic trends for the analysed traits (SET1)

\begin{tabular}{lc}
\hline Trait & Genetic trend \\
\hline Body size and conformation & 0.146 \\
Colour type & 0.034 \\
Colour purity & -0.019 \\
Purity of silvering & 0.017 \\
Coat density & -0.010 \\
Hair length & 0.068 \\
General appearance & -0.003 \\
Total score & 0.231 \\
\hline
\end{tabular}

TABLE 6

Genetic trends for the analysed traits (SET2)

\begin{tabular}{lc}
\hline Trait & Genetic trend \\
\hline Body size and conformation & 0.120 \\
Colour type & 0.033 \\
Colour and silvering purity & -0.007 \\
Quality of hair coat & 0.023 \\
Total score & 0.167 \\
\hline
\end{tabular}

(-0.019 for $\mathrm{CP},-0.010$ for $\mathrm{CD}$, and -0.003 for $\mathrm{GA}$ ) reflects subjectivity of the old grading standard, especially in complex traits (for example GA) when many details need to be evaluated jointly. However, the new grading standard does not seem to be more objective. Although fewer traits were scored (4), and only one estimate of the genetic trend was negative (-0.007 for CSP), in general the genetic progress achieved for the traits, especially the complex ones (CSP and QHC) was low. This may have been brought about by low accuracy of the definition of morphological traits and its wrong interpretation. Furthermore, in the Polish grading standards each trait has its own scale of scores (Tables 1 and 2). Different scales of scores (especially narrow ones) do not permit the reflection of real variability of traits, leading to biased assessments and skewed distribution of scores (Wierzbicki et al., 2000). This problem has been overcome in Norway (Johhannessen et al., 2000). The new grading system introduced in 1995 ensures a good, near to normal distribution of scores since all traits are scored using a 1-5 scale, with 3 as a typical animal.

In Poland the genetic trends for coat and conformation traits in foxes have been estimated using the scores of the old grading standard (Socha, 1996; Jakubczak, 2000; Wierzbicki et al., 2000; Wierzbicki and Filistowicz, 2001).

Jakubczak (2000) estimated the genetic trends in a pastel fox population using the BLUP with a multiple animal model and found low genetic trends for the analysed traits. The annual genetic trend for the total score reached 0.1319. Socha (1996) carried out a study in a blue fox population and also found low genetic trends for 
the conformation traits. The genetic trends ranged from -0.0051 for body size to 0.0734 for total score. In a recent study conducted in the population of arctic fox, Wierzbicki and Filistowicz (2001) found low genetic trends for all analysed traits ranging from 0.00067 for colour type to 0.02822 for total score. The genetic trend estimated for body size was found to be negative (-0.00041).

The results presented above as well as the results of the present study show that the old grading standard was not a good tool for evaluation and genetic improvement of foxes. However, the new grading standard, assumed to be better, did not reveal its advantage.

\section{CONCLUSIONS}

The effect of the new grading standard on estimates of the variance components and the genetic trends of the coat and conformation traits in the silver fox was not clearly demonstrated. Generally, the variance components, heritabilities and the genetic trends estimated using the new scores were comparable to those estimated with the use of the old scores.

Nevertheless, the results of the study should be considered as preliminary since the conclusions were drawn based on analyses of the data that were obtained by transforming old scores into new ones. Although the transformation was done by an experienced classifier, some error might have been introduced. Hence, further investigation based on real data is needed to precisely determine the effect of the new grading standard on genetic parameters and genetic progress in the silver fox.

\section{REFERENCES}

Falconer D.S., Mackay T.F.C., 1996. Introduction to Quantitative Genetics. 4th Edition. Longman House, Burnt Mill, Harlow (England), pp. 228-246

Fernandez C., Steel M.F.J., 1998. On Bayesian modeling of fat tails and skewness. J. Amer. Statist. Assn. 93, 359-371

Filistowicz A., Przysiecki P., Wierzbicki H., Filistowicz A., Tokarska M., 2000. Genetic parameters of coat colour in golden fox (Vulpes vulpes L.). J. Appl. Genet. 41, 259-265

Filistowicz A., Wierzbicki H., Zwolińska-Bartczak I., Żuk B., 1999. Genetic parameters of conformation and coat traits in fox (Vulpes vulpes) population. J. Appl.Genet. 40, 211-217

de la Fuente L.F., Fernandez G., San Primitivo F., 1996. A linear evaluation system for udder traits of dairy ewes. Livest. Prod. Sci. 45, 171-178

Goyache F., del Coz J.J., Quevedo J.R., Lopez S., Alonso J., Ranilla J., Luaces O., Alvarez I., Bahamonde A., 2001. Using artificial intelligence to design and implement a morphological assessment system in beef cattle. Anim. Sci. 73, 49-60

Jakubczak A., 2000. Evaluation of the results of pastel fox breeding in Poland (in Polish). PhD Thesis. Agricultural University of Lublin, pp. 1-19

Jeżewska G., Dąbrowska D., Maciejowski J., Niezgoda G., 1994. Accuracy of external traits evaluation of chinchilla (in Polish). Zesz. Nauk. Prz. hod. 15, 35-43 
Jeżewska G., Maciejowski J., 1983.The extent of difficulty in evaluating the exterior features of different species of fur-bearing animals (in Polish). Zesz. probl. Post. Nauk rol. 302, 83-89

Johhannessen K.R., Borsting E., Kristiansen H., 2000. Live grading as a tool in pelsdyrkontrollen. Scientifur 24 (4), 90-97

Madsen P., Jensen J., 2000. A package for analysing multivariate mixed models. Version 6, release 4. A user's guide to DMU. Danish Institute of Agricultural Sciences (DIAS). Department of Animal Breeding and Genetics, Research Centre Foulum (Denmark)

Manfredi E., Piacere A., Lahaye P., Ducrocq V., 2001. Genetic parameters of type appraisal in Saanen and alpine goats. Livest. Prod. Sci. 70, 183-189

Schaeffer L., Calus M., Liu X., 2001. Genetic evaluation of conformation traits using random contemporary groups and reducing the influence of parent averages. Livest. Prod. Sci. 69, 129-137

Serenius T., Sevón-Aimonen M.-L., Mäntysaari E.A., 2001. The genetics of leg weakness in Finnish Large White and Landrace populations. Livest. Prod. Sci. 69, 101-111

Socha S., 1996. A modification trial of the evaluation and selection of polar blue fox (Alopex lagopus L.). In: Proceedings of the VI ${ }^{\text {th }}$ International Scientific Congress in Fur Animal Production, IFASA. Warsaw (Poland), pp. 205-211

Veerkamp R.F., Gerritsen C.L.M., Koenen E.P.C., Hamoen A., De Jong G., 2001.Evaluation of classifiers that score type traits and body condition score using common sires. J. Dairy Sci. 84, Suppl. 1, 247 (Abstr.)

Wierzbicki H., 2000. Additive genetic and error variance components for conformation and coat traits in arctic fox Alopex lagopus (L.). Scientifur 24 (3), 217-222

Wierzbicki H., Filistowicz A., 2001. Grading versus animal model evaluation in arctic fox (Alopex lagopus). Czech J. Anim. Sci. 46, 252-259

Wierzbicki H., Filistowicz A., Przysiecki P., 2000. Genetic, phenotypic and environmental trends of conformation traits in arctic fox Alopex lagopus (L.). J. Appl. Genet. 41, 113-122

\section{STRESZCZENIE}

\section{Wzorzec oceny i jego wpływ na komponenty wariancyjne i postęp genetyczny w populacji lisa pospolitego}

Dane o cechach produkcyjnych 3637 lisów pospolitych, hodowanych na dwóch polskich fermach w latach 1985-1999, wykorzystano do oszacowania komponentów wariancji oraz trendów genetycznych. W celu sprawdzenia nowego wzorca oceny pokroju, wprowadzonego w 1997 roku, na komponenty wariancji oraz postęp hodowlany przekształcono oceny uzyskane w oparciu o stary wzorzec na odpowiadające im oceny nowego wzorca. Komponenty wariancji oszacowano metodą największej wiarygodności z ograniczeniem (REML), wykorzystując algorytm średniej informacji (AI). Zastosowano model liniowy ze stałymi efektami stada, roku i sezonu urodzenia oraz losowym efektem genetycznym addytywnym zwierzęcia. Trendy genetyczne badanych cech oszacowano jako współczynniki regresji średniej wartości hodowlanej analizowanych roczników zwierząt względem czasu. Stwierdzono niewielki wpływ nowego wzorca oceny na estymatory komponentów wariancji i odziedziczalności badanych cech. Estymatory odziedziczalności uzyskane w oparciu o oryginalne dane znalazły się w przedziale $0,182-0,553( \pm 0,031-0,040)$, i były porównywalne z odziedziczalnościami oszacowanymi z wykorzystaniem danych przekształconych $(0,190-0,355 \pm 0,032-0,039)$. Trendy genetyczne oszacowane dla cech ocenionych przy pomocy starego wzorca znalazły się w przedziale $-0,019$ to 0,231 , i były nieco wyższe niż trendy genetyczne oszacowane dla cech ocenionych według nowego wzorca $(-0,007$ to 0,167$)$. 